\title{
THE BALKANS AND NON-MILITARY SECURITY THREATS - QUALITY COMPARATIVE ANALYSES OF RESILIENCE CAPABILITIES REGARDING HYBRID THREATS
}

\author{
Miroslav MITROVIC, PhD \\ mitrovicmm@gmail.com \\ Strategic Research Institute \\ University of Defense, Republic of Serbia
}

\begin{abstract}
The contemporary security environment indicates non-conventional, asymmetric and hybrid security threats as potentially the most accurate threats to global and regional security. Conflict risks in the regional frame strongly depend on strategically aimed non-military, but hybrid acts. The great powers mostly attempt to achieve their own interests' goals in fulfillment of self-orientated strategic dominance. The Balkan region is a crossroads of strongly exposed interest spheres of regional as well as global powers. The article aims to determine areas of influence in the Balkan States that could become targets of predominantly non-military but hybrid influences. Multi-Value Quality Comparative Analyses (mvQCA) of state power, stability and resilience capacities were used in the research. The methodology used was based on the approach with multi-valued sets of variables and conditions. A theoretical framework was based on contemporary theories of state power and hybrid warfare concept. Used databases were brought together from generated open source databases of approved international academic or think-tank organisations. Based on a hypothesis regarding hybrid security threats, a theoretical framework of understanding of power and analysing a wide spectra of databases, the article aims to contribute a rational and objective understanding of two main indicators: the potential to become a target and the resilience capacities of countries in the face of hybrid security threats. Its findings indicate that most countries in the Balkan region are potentially under unarmed influences and have very low resilience capabilities against
\end{abstract}


possible hybrid influences. The conclusions reached help to clarify that the Balkan States are vulnerable to hybrid security threats.

Keywords: un-conventional security, hybrid security threats, Balkans, Quality Comparative Analyses, national resilience capacities.

\section{Introduction}

'The Balkans are the most geostrategically important region in Europe today, and truth be told, they've held this role for centuries before despite whether or not various Great Powers acknowledged this at the time...The cusp of their contemporary importance is in serving as a geographic facilitator for two Russian and Chinese megaprojects that aim to penetrate the 'unipolar continent' with unshakable multipolar influence, and herein lays the reason why they're the second most likely to fall victim to Hybrid War' (Korybko 2016)

Contemporary literature's discussions about global and regional security promptly contribute to the actualisation of the way non-military or limitedforce predominates and interest groups or other power-based forces prevail. The Balkans are usually colloquially labelled as a region of interest for many regional (Korybko 2016) and global powers (Chivvis 2017). The Balkan States (BS) have in the same role in present (previous communist countries, violence and war history, political, economic and social transition) and future (EU membership, liberal economy, democracy, security cooperation, rule of law) development and solving of regional issues. At the same time, the Balkan region (BR) is recognised as a zone where strategic interests clash with new, hybrid forms of strategic interest for global powers ${ }^{1}$ and regional players ${ }^{2}$.

This research contributes to revealing a gap in the existing research, particularly by applying the Multi-Value Quality Comparative Analyses (mvQCA) methodology in the field of states resilience capabilities against hybrid influences. Considering that the research aimed to closely analyse the capabilities of BS, it could be underlined that the research results indicate that the most resilience capable state

1 Regarding the Correlates to War project, the USA, Russia, UK, France, China, Germany, and Japan are great powers in international relations (the Correlates of War Project n.d.).

2 Regional powers, also known as pivotal powers can be recognised as South Africa, Canada, Argentina, Brazil, Mexico, South Korea, Iran, Saudi Arabia, Israel, Turkey and Australia (Beck 2006; Betz and Taylor 2007). 
in Balkan region is Slovenia, which is strongest in the political, economic, human rights and freedom of media categories. At the same time, Slovenia is highly integrated into the international political and security system. Data indicates that $\mathrm{Kosovo}^{3}$ is the weakest, the most fragile with the burden of a violent history, a comprehensively low social level, rural, with a non-accountable democracy and institutional system, and widespread poverty and economic unsustainability. All other BS are more or less potentially exposed to hybrid influences, and recognised areas of weakness are given in the conclusions.

In this article, the discussion is related to two important topics: to elaborate on the level of potential vulnerability and resilience capabilities of BS regarding hybrid security influences, and to attempt to predict possible niches of future hybrid influences. The research is based on analyses of theoretical postulates of state power and resilience, in the scope of a hypothetical frame of hybrid threat to national stability, through comparing validation of databases in the software support application for mvQCA, TOSMANA v.1.54.

The remainder of the paper is structured as follows. In the next section, the theoretical foundations of state power and resilience capabilities are examined, and a framework of understanding of hybrid security introduced with database sets that were used in the research and introduced with mvQCA. The third section tackles the methodology, logic and variable setting. The last section presents and analyses the results and points at final hypothesis discussion with some recommendations and inconclusive remarks.

3 Kosovo is the southern autonomy region of the Republic of Serbia, which self-declared independence in 2008. OUN doesn't recognise Kosovo as an independent state. The number of states which recognise Kosovo as an independent state is between 106 and 114. Kosovo's status is defined by Resolution 1244 of OUN, and the territory is under observation and the protective presence of OUN and the EU with a strong presence of armed forces, police and administrative staff from the international community. Kosovo has a parliamentary system of governance with the president as an elected leader. All specified characteristics indicate the necessity for introducing Kosovo as a separate subject for analyses, and besides, it is not officially recognised as a state. All references to Kosovo, whether to the territory, institution or population, in this text should not be prejudged and be understood in full compliance with United Nations Security Council Resolution 1244. 


\section{Theoretical framework of state power, resilience, and threats to hybrid security}

The question of vulnerability is a discussion about power. The resilience of some countries to non-military influences is multi-valued, complex, dynamic, changeable and unstable. Predicting possible weakness points on which hybrid influence could be exposed in the aim of accomplishing some-power goals is a demanding but strategically orientated task. Elements of power, which are at the same time signs of weakness, are difficult to measure or quantify. Because of that, the approach to the research should be grounded on theoretical roots and solid indicators and variables assessments.

\section{State power and resilience capacities}

Theoretical findings lead to conclusions that analysis of state power is a very problematic issue in the scope of the actual complexity of international relations (Mišović and Kovač 2006, pp. 30-53). In the approach to analysis of potential strength, power, weakness, vulnerability and resilience potential of countries to security threats, it could be useful to start with Baldwin's (1979) thoughts that power always depends on context. For example, Kulski (1968) suggested that state power could be indicated by material (armed forces, population regarding age, knowledge and skills, economy, science and technology and its rate, geographic position, natural resources etc.) and non-material indicators (quality of foreign policy, moral power and national solidarity of population, political talent and character of state leader's elite etc.). Aron (2003) suggested that it is the location of political subjects, products, and knowledge, which have the potential to become arms, capabilities of collective reaction in the form of armed forces, its discipline, and quality, civil society leadership in peace and war and the solidarity of the state population. Furthermore, since rapid globalisation and the end of the Cold War, visons of power in international relationships are based on indicators such as territory and population, the economy and economic system, and the level of a state's integration and political power (Gavranov and Stojkovic 1972). 
The theory of the complex, multidimensional and hybrid approach to power was introduced by Nye (Nye 2004; Nye 1990) through the Soft and Smart power theory as a result of the global security environment changing, which cause a problem for the previous mostly rational approach to the power of states. Moreover, Nye (2011) recognised that power, with global and technological influences, diverges into new sources and dimensions, compiling the diffusion of power, and is not as easily measured as military power, territory, gross national income, and the structure of the population. Furthermore, power indicators could be presented through the complex synergic interpretation of so-called traditional, soft and smart power. By this approach, the focus of further research could be hybrid power, which is the self-sublimate multivariable dynamic of aggregated indicators. In addition, Nye (2011) suggested that power does not necessarily lead to influence, but could be used in a hybrid combination manner of hard and soft power, and used as a pre-emptive defence potential. In those conditions, it might be considered that power could be recognised as a preventive and resilience capability.

The Balkan region (BR) has a complex history with frozen conflicts in relations among countries there. Also, BR underwent a long and painful transition period from communism to a democracy. There is a rational need for pointing out weak points in the region's structure. The complexities of BR interrelation as well as the countries inner problems are presented in scholars' analyses. Some cover historical burden (Odak and Benčić 2016), democracy implementation (Komar and Živković 2016), the complexity of cooperation with the International Hague tribunal in the scope of EU integration (Subotic 2010), and minority political rights (Lončar 2016; Protsyk and Sachariew 2012; Spirova and Stefanova 2012). Also, political election questions (Obradovic-Wochnik and Wochnik 2014), the International Justice system (Attila Hoare 2010), low implementation problems (Joireman 2016), democratisation and regime sustainability (Alexander 2008), corruption (Aymaliev 2017), and overall postcommunist identity problems (Ekiert et al. 2007) were some of topics.

In the article, power, resilience capabilities of Balkan's countries against particularly non-military, but more hybrid pressures that could jeopardise national and regional security are examined. The approach to power analysis has the aim of delegating two main functions of Balkans states: pre-emptive resilience and effective solving of consequences. 
Hybrid vulnerability in contemporary discussions is a synonym for the exposing of hybrid warfare acts, and in infrequent usage to explain non-military foreign influence and pressure. Those vulnerabilities need to be elaborated on using an analytical approach to the theoretical analyses of scholarly literature.

\section{Hybrid warfare concept}

Hybrid warfare is a term widely used in everyday colloquial discussions, but the idea and the concept of hybrid warfare are not new at all (Watson n.d.). Discussion about recognition delivers a wide range of theoretical and conceptual contributions: asymmetric and 'mixed' conflicts (Messner 1971; Messner 1960), conflicts beyond the conventional and indirect conflicts (Hart 1954; Lind et al. 1989) or as future wars (Slipchenko 1999). Also, works about unrestricted wars (Liang and Xiangsui 1999), network-centric warfare (Cebrowski and Garstka 1998; Savin 2011), chaotic wars (Shashkov 2011; Nazemroaya 2014; Mann 1992), irregular and covert warfare (Eric Rosenbach and Aki J. Peritz 2009) contribute to the topic. Contemporary elaboration of the hybrid warfare concept has been made since 2014 and it is indicated mostly by a non-conventional achievement of strategic interests of power that conduct hybrid attacks ${ }^{4}$.

All the above listed scholarly works underline a group of indicators, or potential challenges for national security which are non-military but more hybrid, such as: economic weakness, lack of democracy, an undeveloped political system, a dysfunctional state, a lack of state sovereignty, media and internet manipulation, the existence of frozen conflicts, unresolved territorial disputes, the presence of arbitration or control of a territory by supranational entities, ethnic and religious problems, separatism, extremism, unemployment, the existence of general poverty, long-term dissatisfaction of the population with the political and social

4 Contemporary hybrid warfare is mostly analysed as the non-armed achievement of strategic dominance trough 'coloured revolution', cyber-attacks, involving in separatists movements, support of some ideologies or ethnical extremist organizations, propaganda information campaigns, economical and energy pressure, etc. Work which presents most of the listed forms are (McCulloh and Johnson 2013; Renz and Smith 2016; Korybko 2015; Kofman and McDermott 2015) 
solutions of the country's leadership, corruption, powerful criminal elements, institutions with separate centres of power and governance, etc. In the correlation to listed indicators, looking through the scope of hybrid threats four basic pillows of the hybrid concept of security (Mitrovic 2017):

- Special and psychological operations - limited time performance, high intensity with very significant direct effects. Mostly used for escalation and the final stage of accomplishments of a hybrid strategy.

- Economic, energy and political pressures - actions of variable duration and intensity, depending on the interaction, relationship and buck effects which could be affected by the side who applies pressure.

- Information, media, internet and its platforms - variable intensity activities, depending on the phase of other forms/fields implementation. Time of submission is usually long-term and depends on the goals and the phase of implementation of other hybrid activities.

- Public diplomacy-low-intensity, very long-term-oriented, comprehensive hybrid operation tool, which makes it more diverse in the sphere of social life: culture, education, education, religion, the entertainment industry, nongovernmental organisations, political movements and associations, civil initiatives and others that are undertaken to influence public opinion.

All listed forms of activities have the purpose of destabilising the country or changing political and government power in it, organised and carried out with the purpose of achieving the strategic interests of external power centres, in order to establish the state of disruption of balance in international relations, and realisation of their own interests, mostly by non-combat means. On the basis of these theories, it could be concluded that hybrid warfare does not present warfare per se, but a form of conflicting concept in which a wide range of military and non-conventional activities are applied, with the purpose of achieving strategic advantages for applying entity.

Besides military aspects (special and psychological operations), which will not be analysed in this research, because of its more executive and hard power related nature, the focus of the article is on soft and smart indicators of hybrid threats to security. Namely, in the mvQCA analyses process, databases which are related with a political system, political stability, transparency of government and civil control, economic development, energy safety, the fragility of the transition state 
system, corruption, freedom of the media, history, and state of conflicts and disputes are involved.

Contemporary and ongoing security issues, defence, political, economic, energy cultural and media, as well as relations with international organisational, state integration in the EU and NATO, indicate interactive events of global and regional powers in Balkan region. This leads to the hypothesis:

Hypothesis 1: Balkan states are exposed to non-military but hybrid external influence.

Hypothesis 2: Balkan countries are vulnerable to non-military, hybrid attacks.

\section{Methodology, logic and variable setting and TOSMANA mvQCA proceeding}

Basically, the methodology used is founded on the Qualitative comparative analysis (QCA), which is both a research approach and a data analysis technique. QCA has been characterised as a new, contemporary way to conduct social science research that combines the strengths of traditional quantitative and qualitative methods. It was presented by Ragin, Mayer, and Drass (1984), as the method of Qualitative Comparative Analysis (QCA) (Ragin 2009; Ragin 2000) and the contribution elaborated on in the work of Rihoux and Ragin (2009). Up to now, researchers in the fields of social science, such as sociologists, political scientists, and management scholars have found that application of QCA methodology approach has wide applicable potential in future social science research.

\section{What are Quality Comparative Analyses and Multi-Value Quality Comparative Analyses?}

In general, Multi-Value Quality Comparative Analyses (mvQCA) is one of the interpretations of Quality Comparative Analyses (QCA), which aims to compare 
cases systematically while still preserving a strong focus on individual cases ${ }^{5}$. The goal of most QCA is thus to explain all cases as comprehensively as possible by taking into account a set of explanatory factors and their complex combinations. On the contrary, variable-oriented methods are focused on the net effects of one or more variables over a large number of cases. Such an approach allows researchers to generalise their findings more easily but usually does not lead to encompassing complex explanations for a given phenomenon (Fischer 2014).

In general, the case orientation of QCA fits well with the wide spectra of social science research, which seek out the factors causing a given phenomenon, such as law-making outputs (Christmann and Danaci 2012), government spending (Vis 2011), coalition formation and policy change (Fischer 2014), or the success of policy projects (Verweij et al. 2013), welfare states (Avdagic 2010), social movements (Wright and Boudet 2012), labour markets (Dixon et al. 2004), and corporate governance (Bell et al. 2014). Some researchers in international relations and security indicate the link between resources scarcity and armed conflicts (Bretthauer 2015) based upon QCA, a third party involved in war crimes (Berlin 2016), specific interactions between partisan politics and the benefits states wish to secure by contributing to a multilateral intervention operation (Haesebrouck 2017) or the logic of UN intervention response (Binder 2015). However, implementation of a QCA methodology in security and international relations issues seems to contribute more objective findings of social and political science.

In short, a QCA generally aims to explain elements of the social science reflected process as well as its outputs and outcomes that lie at the end of a (hypothetically) complex causal chain. Moreover, the QCA test the hypothesis or existing theories and contribute to developing new theoretical arguments in form of the hypothesis (Rihoux and De Meur 2009). It could be said that a QCA is '....the approach [that] might be better characterised as an attempt to redesign or transcend existing qualitative and quantitative approaches, not substituting them but complementing them under certain circumstances" (Devers et al. 2013). For this reason, the QCA approach needs to be critically applied, with carefully selected variables

5 Logic and explanation of Quality Comparative Analyses (QCA) could be found in (Ragin et al. 1984; Rihoux and Ragin 2009) 
and clarified criteria, just because of possible ambiguities that are indicated (Baumgartner and Thiem 2017). In this research, mvQCA is implemented (Cronquist and Berg-Schlosser 2009), which considers the usage of multi-value variables, with contemplation for preventing information loss and a large number of contradictory configurations are considered, which could be a case in basic QCA, or Crisp-set Quality Comparative Analyses (csQCA) (Rihoux and De Meur 2009) and considers a metalogic created notation (Cronquist and Berg-Schlosser 2009). In general, mvQCA was developed to meet the limitations of csQCA and prevent a simplified dichotomous approach in multivalued, aggregated variables usage. In the research, csQCA was applied in the second stage of case analyses, to support findings and case sensitivity visualisation settings.

\section{Databases of aggregated variables}

Data for theory checking is introduced upon an assessment of drivers that contribute to state power and its stability. The main indicators of aggregate databases introduce political stability, political system, and stability of governance, corruption sensitivity and fragility regarding valiant political acts, economic strength, and development, free-market orientation, the role of law, civil society freedom and transparency of governance, freedom, and the structure of the media. Databases are related to the security and have a broad reliability rate based on institutional recognition and the methodology approach involved. The following databases ${ }^{6}$ were used in the research: the Bertelsmann Transformation Index (BTI) (Bertelsmann n.d.), Corruption Perceptions Index (CPI) (Transparency International n.d.), Countries at the Crossroads (COUCROS) (Freedom House n.d.), Major Episodes of Political Violence Effectiveness (MEPV) (Center for Systemic Peace n.d.) and Freedom of the Press (WRPF) (Freedom House n.d.).

6 Listed data bases, among others, are generated from the Catalogue of Databases for Security-related Research in (Dimitrijevic and Parausuc 2017) 


\begin{tabular}{|c|c|c|}
\hline Variable & Database & Aggregated multi-valued variables \\
\hline BTI & $\begin{array}{l}\text { Bertelsmann } \\
\text { Transformation } \\
\text { Index }\end{array}$ & $\begin{array}{l}\text { stateness, political participation, rule of law, stability of } \\
\text { democratic institutions, political and social integration, } \\
\text { level of socioeconomic development, organisation of the } \\
\text { market and competition, currency and price stability, } \\
\text { private property, welfare regime, economic performance, } \\
\text { sustainability, level of difficulty, steering capability, resource } \\
\text { efficiency, consensus-building, international cooperation }\end{array}$ \\
\hline CPI & $\begin{array}{l}\text { Corruption } \\
\text { Perceptions Index }\end{array}$ & $\begin{array}{l}\text { transparency, accountability, and corruption in the } \\
\text { public sector, auditing of state spending; regulation of } \\
\text { party financing; citizen and media access to information; } \\
\text { accountability of officeholders (asset declarations, conflict } \\
\text { of interest rules, codes of conduct); transparent public } \\
\text { procurement systems; effective prosecution of corruption }\end{array}$ \\
\hline COUCROS & $\begin{array}{l}\text { Countries at the } \\
\text { Crossroads }\end{array}$ & $\begin{array}{l}\text { government accountability, civil liberties, rule of law, and } \\
\text { anti-corruption and transparency efforts, involving of the } \\
\text { system in political efforts, electoral freedom, campaigns, } \\
\text { financing of political parties, the role of law, independent and } \\
\text { efficiency of law system civil right and freedom, involving of } \\
\text { state in the economy }\end{array}$ \\
\hline MEPV & $\begin{array}{l}\text { Major Episodes of } \\
\text { Political Violence } \\
\text { Effectiveness }\end{array}$ & $\begin{array}{l}\text { security legitimacy, political legitimacy, economic legitimacy } \\
\text { and social legitimacy, armed conflict indicator, regime type, } \\
\text { net oil production or consumption, regional effects, political } \\
\text { effectiveness, economic effectiveness, social effectiveness }\end{array}$ \\
\hline WRPF & $\begin{array}{l}\text { Freedom of the } \\
\text { Press }\end{array}$ & $\begin{array}{l}\text { law environment, laws which influence the media and its } \\
\text { freedom of expression and press organisation, political } \\
\text { environment, level of political control of media, editorial } \\
\text { independence of private and public media, availability of } \\
\text { sources of news, censuring, and auto censuring, freedom } \\
\text { of reporting, repercussions for reporters, economic } \\
\text { environment of importance for media functioning, } \\
\text { ownership, transparency of media ownership, influence of } \\
\text { corruption on the media, and the economic situation of the } \\
\text { state's affect on the media }\end{array}$ \\
\hline
\end{tabular}

${ }^{+}$Description of variables used in the mvQCA process of comparing the power/resilience of the Balkan states against non-military threats to security.

\section{Table 1. Multi-valued variables gathered from databases}

The software platform TOSMANA $1.54^{7}$ was used to analyse the mvQCA research.

7 The software application with manuals for using TOSMANA 1.54 is available at http:// www.tosmana.net [accessed 10 Jan 2018]. 


\section{Settings of variable logic and their values}

The foundry based theory in the research indicates sets of variables that are observed. Case descriptions indicate that the observed subjects are present in a variable set of Balkan states (BSTAT): Albania, Bosnia and Herzegovina, Bulgaria, Croatia, Kosovo, Macedonia, Montenegro, Romania, Serbia, and Slovenia

For the purpose of validating the logic ('low-high'), some original values of variables are a market '-' with a purpose to meet the necessity of value unification and merger of calculation in a logic frame of a difference of variable expression. Namely, in conditions variables, BTI, CPI, and WRPF, scaling numbers are a market with '-' to allow the logic which is that lowest values amplify criteria closes to a dedicated logic system of values. For the purpose of creating a balanced and unique logical frame, indicators for ' 0 ,' ' 1 ' and ' 2 ' correspond with a description of the original value scaling system, given a '-' pre-mark.

In this particular research, mvQCA allows multinomial categorical data to be used ( 0,1 and 2). As results of analyses, indicators of numerical values are set by logic criteria:

'O' - no particularly hybrid vulnerability, high resilience capacities.

' 1 ' - possible hybrid vulnerability, predicted possibilities of hybrid acts.

'2' - strongly exposed hybrid vulnerability, low resilience capabilities.

The data table was created in TOSMANA application and appears as Fig. 1.

\begin{tabular}{|c|c|c|c|c|c|c|c|}
\hline \multicolumn{8}{|c|}{ D2 - Tosmana } \\
\hline File & Data (mv)QCA & fs QCA $A b$ & & & & & \\
\hline \multirow[t]{12}{*}{ Data } & Data for QCA & & & & & & \\
\hline & WBSTAT & $\begin{array}{l}\text { BTI } \\
\text { 量 }-8.12 ;-7.22\end{array}$ & $\begin{array}{l}\mathrm{CPI} \\
\text { 酋 }-52.67 ;-44.33\end{array}$ & $\begin{array}{l}\text { COUCROS } \\
\text { 鼻 } 3.01: 3.99\end{array}$ & 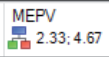 & $\begin{array}{l}\text { WRPF } \\
\text { 鼻 }-43.47 ;-33.97\end{array}$ & OUTCAM \\
\hline & Albania & -6.71 & -39 & 4.14 & 2 & -29.92 & 1 \\
\hline & Bosnia and Herz... & -6.38 & -39 & 4.54 & 4 & -27.83 & 1 \\
\hline & Bulgaria & -7.91 & -41 & 3.29 & 2 & -35.01 & 1 \\
\hline & Croatia & -7.93 & -49 & 3.71 & 2 & -29.59 & 1 \\
\hline & Kosovo & -6.33 & -36 & 4.96 & 7 & -30.45 & 1 \\
\hline & Macedonia & -6.86 & -37 & 4.43 & 2 & -35.74 & 1 \\
\hline & Montenegro & -7.48 & -45 & 3.89 & 3 & -33.65 & 1 \\
\hline & Romania & -8.06 & -48 & 3.39 & 4 & -24.46 & 1 \\
\hline & Serbia & -7.43 & -42 & 3.82 & 3 & -28.05 & 1 \\
\hline & Slovenia & -9.01 & -61 & 2.04 & 0 & -52.98 & 0 \\
\hline$m$ & & & & & & & \\
\hline
\end{tabular}

Fig. 1 Designed table for $m v Q C A$ with variables and data 
In Two level thresholds are used for the purpose of indicating the area of variable criteria influence. TOSMANA generated thresholds divergences by variables regarding two levels of criteria are shown in Fig. 2 to 6.

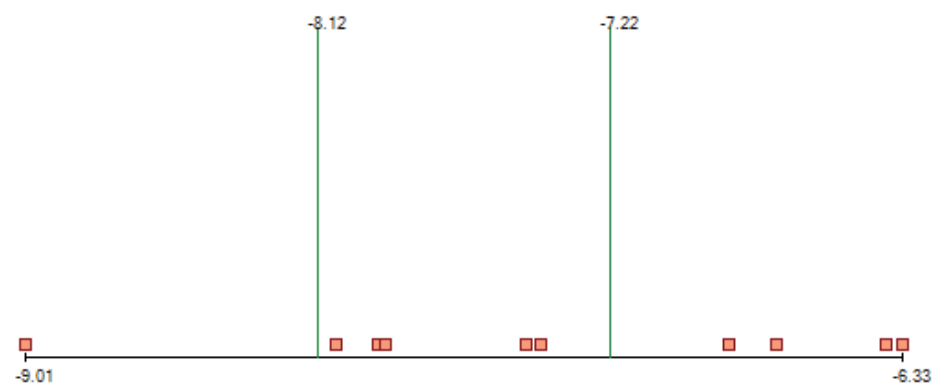

Fig. 2. Thresholds divergence for variable BTI

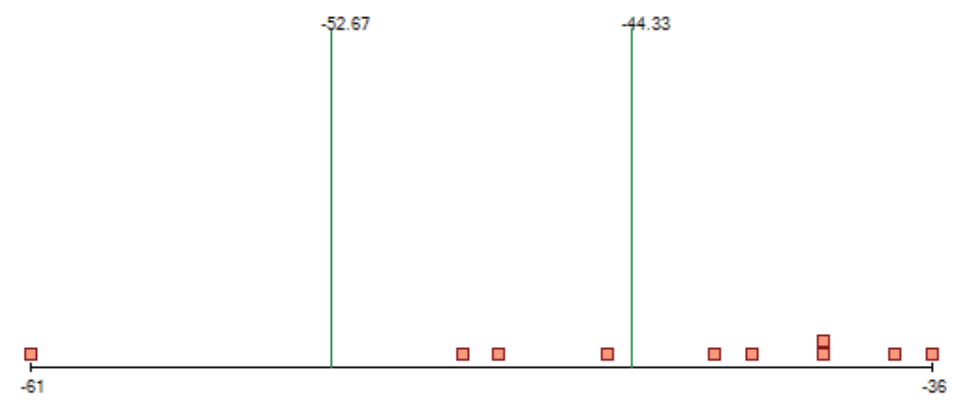

Fig. 3. Thresholds divergence for variable CPI

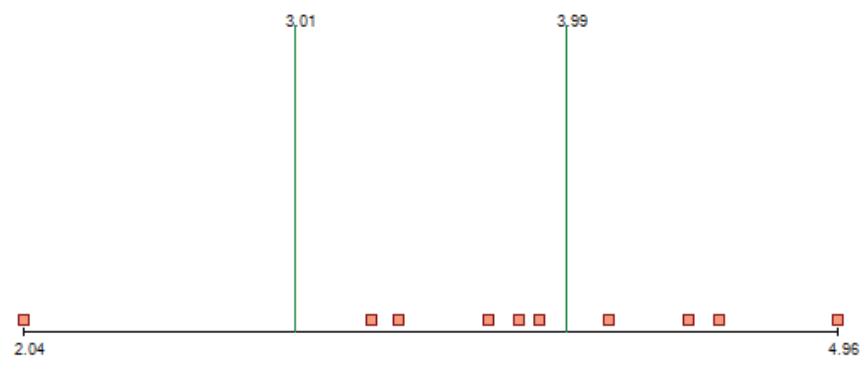

Fig. 4. Thresholds divergence for variable COUCROS 


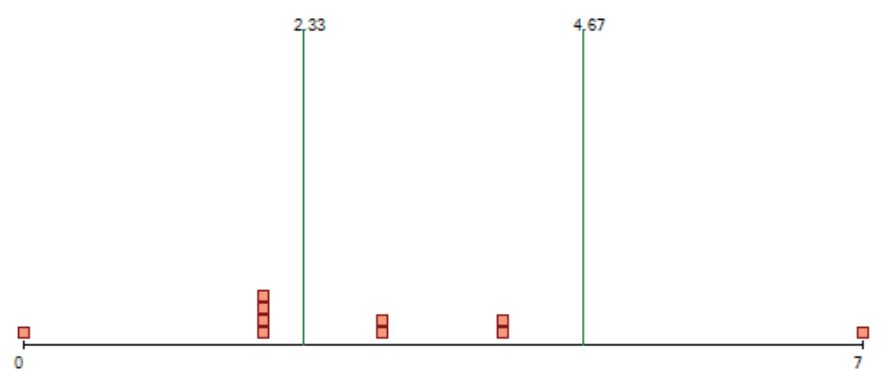

Fig. 5. Thresholds divergence for variable MEPV

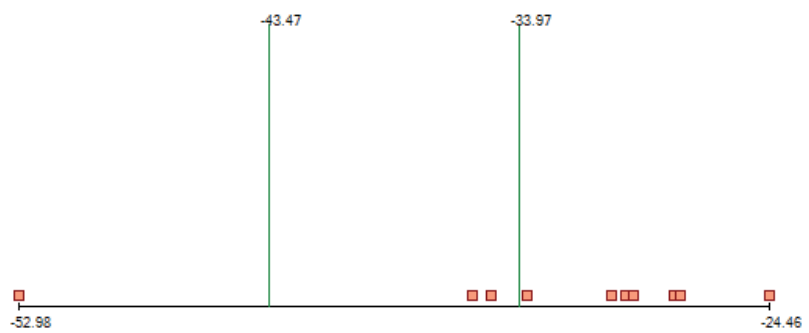

Fig. 6. Thresholds divergence for variable WRPF

After applying the mvQCA calculation in TOSMANA, results of analyses are expressed in Table 2. below.

\begin{tabular}{|l|l|l|l|l|l|l|}
\hline BSTAT & BTI & CPI & COUCROS & MEPV & WRPF & OUTCOME \\
\hline Slovenia & 0 & 0 & 0 & 0 & 0 & 0 \\
\hline Croatia & 1 & 1 & 1 & 0 & 2 & 1 \\
\hline Montenegro, Romania & 1 & 1 & 1 & 1 & 2 & 1 \\
\hline Bulgaria & 1 & 2 & 1 & 0 & 1 & 1 \\
\hline Serbia & 1 & 2 & 1 & 1 & 2 & 1 \\
\hline Macedonia & 2 & 2 & 2 & 0 & 1 & 1 \\
\hline Albania & 2 & 2 & 2 & 0 & 2 & 1 \\
\hline Bosnia and Herzegovina & 2 & 2 & 2 & 1 & 2 & 1 \\
\hline Kosovo & 2 & 2 & 2 & 2 & 2 & 1 \\
\hline
\end{tabular}

${ }^{+}$Algorithm Settings including: Minimizing: 01 including C; Variable Thresholds Settings: BTI=(8.12,-7.22); $\mathrm{CPI}=(-52.67,-44.33) ; \mathrm{COUCROS}=(3.01,3.99) ; \mathrm{MEPV}=(2.33,4.67) ; \mathrm{WRPF}=(-43.47,-$ 33.97).

Table 2. Results of the calculation process in TOSMANA on criteria for mvQCA 
Equations of logic expression for the mvQCA process are:

$\operatorname{BTI}\{2\} * \operatorname{CPI}\{2\} * \operatorname{COUCROS}\{2\} * \operatorname{WRPF}\{2\}+($ Albania+Bosnia

and Herzegovina+Kosovo)

$\operatorname{BTI}\{1\} * \operatorname{CPI}\{2\}{ }^{*} \operatorname{COUCROS}\{1\} * \operatorname{MEPV}\{0\} * \operatorname{WRPF}\{1\}+($ Bulgaria $)$

$\operatorname{BTI}\{1\} * \operatorname{CPI}\{1\}\}^{*} \operatorname{COUCROS}\{1\}{ }^{*} \operatorname{MEPV}\{0\} * \operatorname{WRPF}\{2\}+($ Croatia)

$\operatorname{BTI}\{2\}\}^{*} \operatorname{CPI}\{2\} * \operatorname{COUCROS}\{2\} * \operatorname{MEPV}\{0\} * \operatorname{WRPF}\{1\}+($ Macedonia)

BTI $\{1\}$ *CPI $\{1\} * \operatorname{COUCROS}\{1\} * \operatorname{MEPV}\{1\} * \operatorname{WRPF}\{2\}+$ (Montenegro, Romania)

$\operatorname{BTI}\{1\}\}^{*} \operatorname{CPI}\{2\} * \operatorname{COUCROS}\{1\} * \operatorname{MEPV}\{1\} * \operatorname{WRPF}\{2\}+($ Serbia)

$\operatorname{BTI}\{0\} * \operatorname{CPI}\{0\} * \operatorname{COUCROS}\{0\} * \operatorname{MEPV}\{0\} * \operatorname{WRPF}\{0\}+($ Slovenia)

Regarding derived values of multi-value QCA ('2,"1' and ' 0 '), all BS, with the exception of Slovenia, have significant dedicated values of vulnerability against hybrid threats to national security. According to these derived values, Crisp-set Qualitative Comparative Analysis (csQCA) was created, with the purpose of indicating potentially existing hybrid attempts.

A one level threshold is used for the purpose of indicating the area of criteria influence and csQCA analyses.

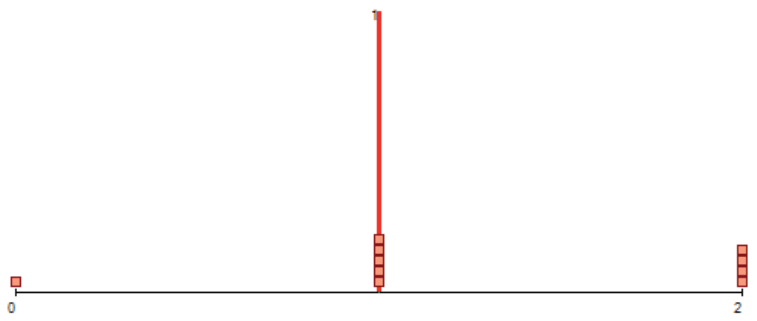

Fig. 7. Thresholds divergence for variable BTI (csQCA) 


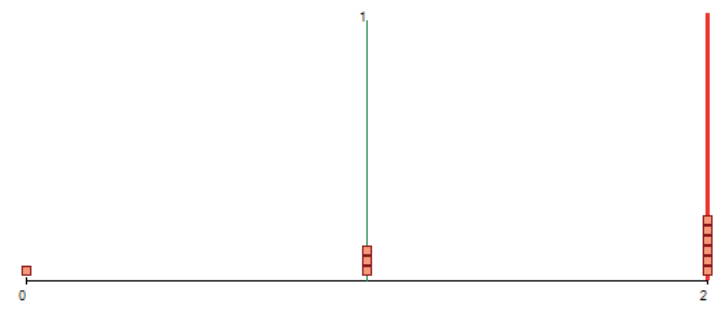

Fig. 8. Thresholds divergence for variable CPI (csQCA)

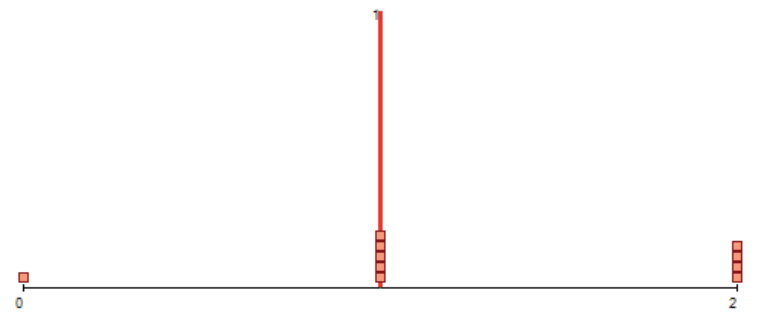

Fig. 9. Thresholds divergence for variable COUCROS (csQCA)

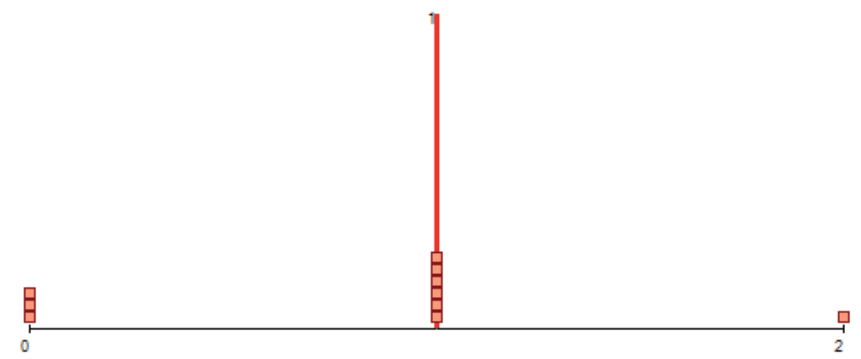

Fig. 10. Thresholds divergence for variable MEPV (csQCA)

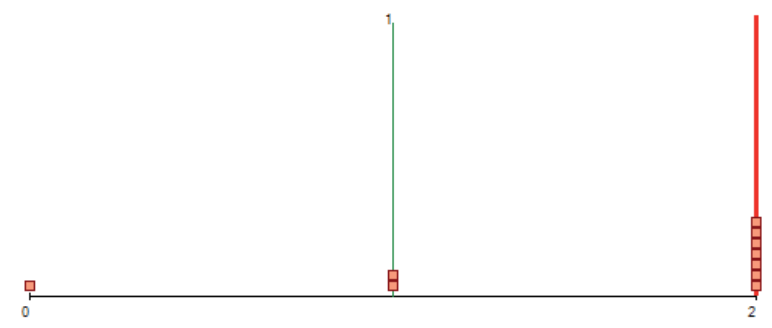

Fig. 11. Thresholds divergence for variable WRPF

A dta table for the criteria was created in the TOSMANA application and is shown in Fig. 12. 


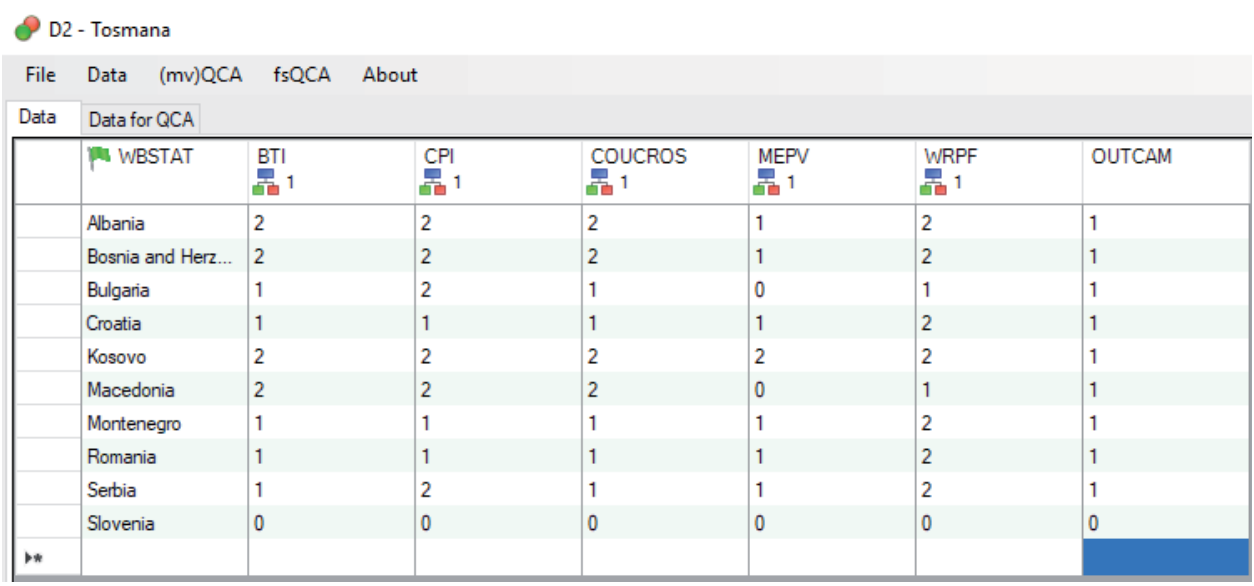

Fig. 12. Designed table for csQCA with variables and data

After applying for an csQCA calculation in TOSMANA, results of analyses are shown in Table 3.

\begin{tabular}{|l|l|l|l|l|l|l|}
\hline BSTAT & BTI & CPI & COUCROS & MEPV & WRPF & OUTCOME \\
\hline Slovenia & 0 & 0 & 0 & 0 & 0 & 0 \\
\hline Croatia, Montenegro, Romania & 0 & 0 & 0 & 0 & 1 & 1 \\
\hline Bulgaria & 0 & 1 & 0 & 0 & 0 & 1 \\
\hline Serbia & 0 & 1 & 0 & 0 & 1 & 1 \\
\hline Macedonia & 1 & 1 & 1 & 0 & 0 & 1 \\
\hline $\begin{array}{l}\text { Albania, Bosnia and } \\
\text { Herzegovina }\end{array}$ & 1 & 1 & 1 & 0 & 1 & 1 \\
\hline Kosovo & 1 & 1 & 1 & 1 & 1 & 1 \\
\hline
\end{tabular}

${ }^{+}$Algorithm Settings including: Minimizing: 01 including C; Variable Thresholds Settings: BTI=(1); $\mathrm{CPI}=(1) ; \mathrm{COUCROS}=(1) ; \mathrm{MEPV}=(1) ; \mathrm{WRPF}=(1)$.

Table 3. Results of the calculation process in TOSMANA upon criteria for csQCA

Equations of logic expression for the mvQCA process are:

bti*coucros*mepv+(Bularia+Croatia,Montenegro,Romania+Serbia+Slovenia) (8)

$\mathrm{BTI}^{*} \mathrm{CPI}^{*} \mathrm{COUCROS}{ }^{*} \mathrm{WRPF}+($ Albania,Bosnia and Herzegovina+Kosovo)

$\mathrm{BTI}^{*} \mathrm{CPI}{ }^{*} \mathrm{COUCROS} * \mathrm{mepv}($ Albania,Bosnia and Herzegovina+Macedonia)

Results lead to the conclusion that all observed Balkan countries, with the exception of Slovenia, are potentially recognised as having low resilience against 
hybrid attacks, which marks them as potential targets of interest and for various strategies and operational approaches.

A Venn diagram corresponding to the findings in (8), (9) and (10) shows the visualisation of the csQCA process derived by dedicated criteria in Fig. 13.

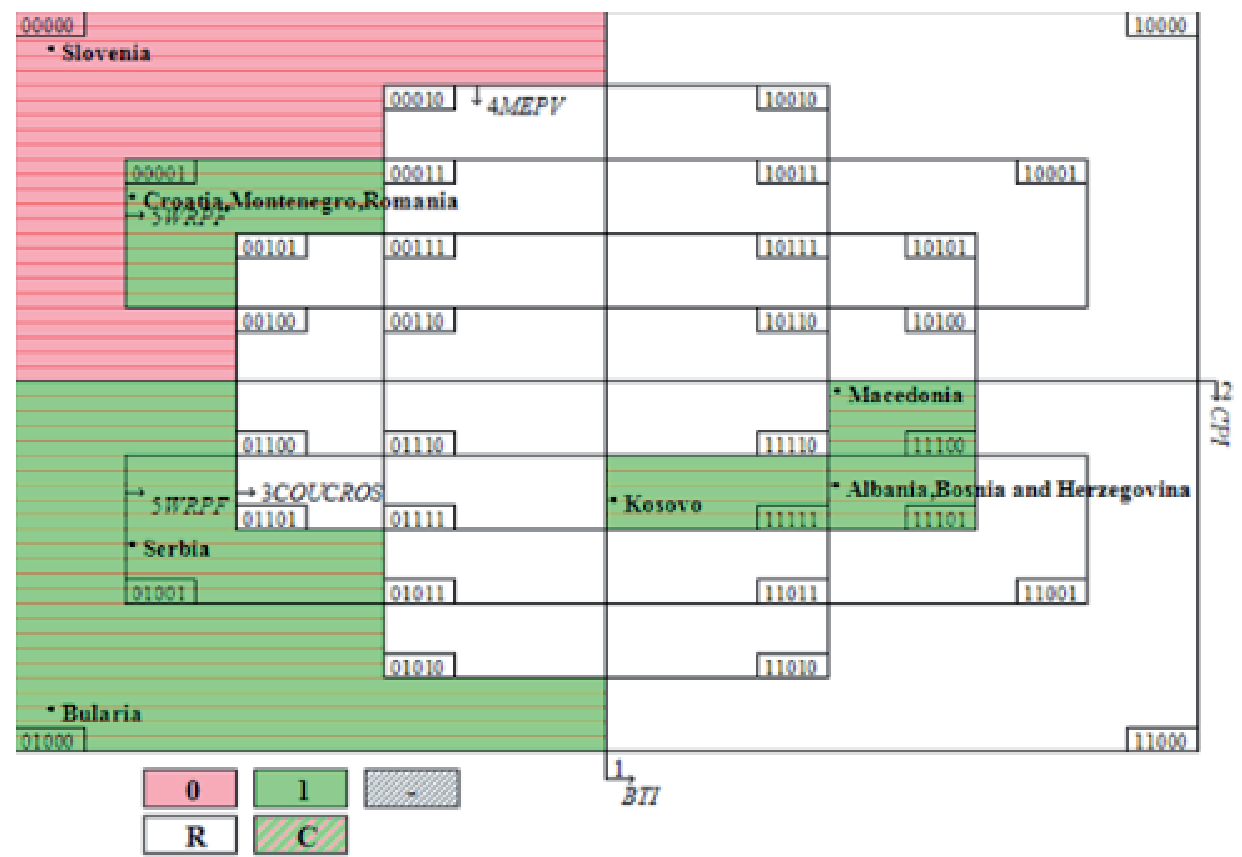

Fig. 13. Venn diagram corresponding to Table III, produced by the 'visualiser' tool, TOSMANA 1.54

\section{Findings of QCA regarding non-military resilience capacities of BS states}

Outcomes that are produced by TOSMANA upon a logic set of variables, and generated from databases, reveal the following findings:

a) Based on equation (8), Bulgaria, Croatia, Montenegro, Romania, Serbia, and Slovenia are under modest, low-intensity non-military pressure. In addition, it is possible to indicate that by some specifications, countries are separated into subgroups or they have some unique examples: Bulgaria (some unique), Croatia, Montenegro and Romania (subgroup with some unique), Serbia (some unique) 
and Slovenia (some unique). Using equation (8) is reveals that listed countries have low, unknown but present hybrid pressure in variable values groups which are illustrated in BTI, COUCROS, and MEPV.

a1) Equation (9) indicates a strong presence of hybrid pressure on Albania, Bosnia and Herzegovina and Kosovo (with some specification) in the area covered by BTI, CPI, COUCROS, WRPF variables.

a2) Equation (10) indicates a strong presence of hybrid pressure on Albania, Bosnia and Herzegovina and Macedonia (with some unique) in the area covered by BTI, CPI, COUCROS variables, and with low intensity, but predicting a possible present influence in the MEPV set of variables.

Analysis of the Venn diagram (Fig. 13) indicates that Slovenia is outside hybrid influence that could be labelled an actual threat to national capacities.

Influence in the media and public audience management (WRPF) is indicated in Croatia, Montenegro, and Romania.

Results indicate that Bulgaria is under pressure in the zone of the COUCROS group of variable parameters. Serbia is under strong hybrid influence in the area of free media, communications and public audience management (WRPF), which is in synergy pressure in the COUCROS group of parameters (see Table 1).

The most exposed to hybrid pressure is Kosovo by all criteria, followed by Albania and Bosnia and Herzegovina and Macedonia. The descriptive formula which expresses the conditions in listed countries is:

BTI*CPI*COUCROS* $\left\{\begin{array}{l}\text { WRPF } \\ \text { mepv }\end{array}\right.$

Equation (11) is read as follows:

The considerable hybrid pressure in Albania, Bosnia, and Herzegovina, Macedonia and Kosovo is in all areas of political and social life, including the economy, energy, democracy, rule of law, public security and state governance. The cumulative effect of pressure is expressed through limited freedom of the press, media manipulation, and intensive public audience management to support hybrid attacks. All findings 
indicate modest, latent but existing possibilities for violent episodes connected to of the achievement of hybrid goals.

Overall conclusions from previous arguments indicate the approval of Hypothesis 1: Balkan states are exposed to non-military but hybrid influence of outside powers. The intensity and areas of influence can be revealed more closely in relation to the specific group of countries or individual countries, which could be a starting point for some future researchers.

b) Expressions of the interaction of variables with data sets indicate founder data is for multi-values qualitative-comparative analyses. With this information in mind, itis possible to indicate groups of resilience/ vulnerability indicators for groups or separate countries. Logical calculations in equations (1) to (7) indicate that some groups of variables care related to the grouping of states regarding similarity of expressions:

- Albania, Bosnia and Hercegovina have an exception for MPV vulnerability, and similar strong weakness in areas of BTI, CPI, COUCROS and WRPF indexes conditions.

- Montenegro and Romania have the same logic results in all indicators. These two countries are potentially under hybrid influence, but the most significant lack of resilience is in the area of WRPF.

- Bulgaria, Croatia, Macedonia, and Serbia are exposed to similar hybrid acts. Lack of resilience is different from country to country, but overall conclusions indicate that all four countries are potentially exposed to hybrid actions, have some level of vulnerability against hybrid threats and that it is possible to indicate specific areas of possible influence (BTI, CPI, COUCROS, and WRPF).

- Slovenia has the most developed resilience capabilities. In this case, Slovenia could be observed as an example or correlated factorial for Western Balkan stability and cohesion.

- Kosovo has zero resistance against possible future hybrid attacks. The situation is critical in all listed areas of generic variable indicators (see Table 1).

The overall conclusion of multi-values analyses indicates partial approval of Hypothesis 2:

Balkan countries, with the exception of Slovenia, are vulnerable to non-military, hybrid attacks, which means they are potential targets for such operations. Areas 
of vulnerability and lack of resilience capabilities are different, as well as a level of capabilities. Indicators, which could bring clearer conclusions, may be developed for each country, supported by more precise analytical methodology such as Fuzzy Sets QCA (fsQCA) (Ragin 2009) and individual database sets. In this way, areas of necessary national resilience capacity development can be identified with greater precision.

\section{Conclusions}

The Balkans' is declared as a 'region of interest' by global and regional powers. In contemporary analyses made by politicians, journalist and scholars, attempts by the great powers to achieve their own strategic goals and preponderance in the Balkans are highlighted, mainly without the use of military means. Contemporary geopolitical relations, evaluation of conflicts, new doctrines and strategies, supported by the escalation of technology, economic interdependence, energy instability and differences in the understanding of democracy and governance, forcefully introduce a not completely new, but more uncertain, hybrid global security environment. In an effort to make variable based, comparative and qualitative analytics supported arguments, this research has raised a hypothesis by which it attempts to clarify or deny colloquial and describable conclusions about the presence of hybrid security threats and hybrid resilience niches in the countries of the Balkan region. The conclusion of multivariable generated analyses indicates existing hybrid security threats in all Balkan countries, with variable sets of different areas of influence. In addition, all countries, with the exception of Slovenia, have variable, but obvious 'weak areas' in their own existing political, economic and media practices. Based on these findings, it is possible to predict that most Balkan countries could and will become future targets for hybrid attacks. It is also clear that every specific country needs deep analytic work to identify the most vulnerable areas, by which strategies for resilience empowerment could be developed. Some also point to the possibility of using the QCA methodology approach in the definition and analyses of foreign politics, security and defence. 


\section{References}

Alexander, M., 2008. Democratization and Hybrid Regimes: Comparative Evidence from Southeast Europe. East European Politics E Societies, 22 (4), 928-954. [online] Available from: http://eep.sagepub.com/cgi/doi/10.1177/0888325408327634 [Accessed 6 Feb 2018].

Aron, R., 2003. Peace \& war: a theory of international relations. New Brunswick New Jersey: Transaction Publishers.

Attila Hoare, M., 2010. Bosnia-Hercegovina and International Justice: Past Failures and Future Solutions. East European Politics E Societies, 24 (2), 191-205. [online] Available from: http://eep.sagepub.com/cgi/doi/10.1177/0888325409356462 [Accessed 25 Jan 2018].

Avdagic, S., 2010. When Are Concerted Reforms Feasible? Explaining the Emergence of Social Pacts in Western Europe. Comparative Political Studies, 43 (5), 628-657. [online] Available from: http://journals.sagepub.com/doi/10.1177/0010414009356178 [Accessed 25 Jan 2018].

Aymaliev, I. M., 2017. Corporate Motivations for Donating to the Police in Bulgaria. East European Politics and Societies. [online] Available from: http://journals.sagepub.com/ doi/10.1177/0888325417710080 [Accessed 25 Jan 2018].

Baldwin, D. A., 1979. Power analysis and world politics: New trends versus old tendencies. World politics, 31(2).

Baumgartner, M. and Thiem, A., 2017. Model Ambiguities in Configurational Comparative Research. Sociological Methods \& Research, 46 (4), 954-987. [online] Available from: http://journals.sagepub.com/doi/10.1177/0049124115610351 [Accessed 25 Jan 2018].

Beck, M., 2006. The Concept of Regional Power - The Middle East as a Devian Case. In German Institute of Global and Area Studies. Hamburg.

Bell, R. G., Filatotchev, I. and Aguilera, R. V., 2014. Corporate Governance and Investors' Perceptions of Foreign IPO Value: An Institutional Perspective. Academy of Management Journal, 57(1), pp. 301-320. [online] Available from: http://journals. aom.org/doi/10.5465/amj.2011.0146 [Accessed 25 Jan 2018].

Berlin, M. S., 2016. Why (not) arrest? Third-party state compliance and noncompliance with international criminal tribunals. Journal of Human Rights, 15 (4), 509-532. [online] Available from: https://www.tandfonline.com/doi/full/10.1080/14754835.20 15.1103160 [Accessed 25 Jan 2018].

Bertelsmann, BTI - Bertelsmann Transformation Index. BTI - Bertelsmann Transformation Index. [online] Available from: https://www.bti-project.org/en/home/ [Accessed 25 Jan 2018].

Betz, J. and Taylor, I., 2007. The Rise of (new) regional powers in Asia, Africa, Latin America-contribution to regional and world peace or protracted conflicts. Workshop presented at the European Consortium for Political Research Joint Sessions. 
Binder, M., 2015. Paths to intervention: What explains the UN's selective response to humanitarian crises? Journal of Peace Research, 52 (6), 712-726. [online] Available from: http://journals.sagepub.com/doi/10.1177/0022343315585847 [Accessed 25 Jan 2018].

Bretthauer, J. M., 2015. Conditions for Peace and Conflict. Journal of Conflict Resolution, 59(4), pp. 593-616. [online] Available from: http://journals.sagepub.com/doi/10.1177 /0022002713516841 [Accessed 25 Jan 2018].

Cebrowski, A. and Garstka, J., 1998. Network-centric warfare: Its origin and future. US Naval Institute Proceedings.

Center for Systemic Peace, MEPV - Major Episodes of Political Violence Effectiveness. [online] Available from: http://www.systemicpeace.org/inscrdata.html [Accessed 25 Jan 2018].

Chivvis, C.S., 2017. Understanding Russian "Hybrid Warfare" And What Can Be Done About it. RAND Cooperation, pp. 1-12. [online] Available from: http://www.rand. org/pubs/testimonies/CT468.html [Accessed 31 Jan 2018].

Christmann, A. and Danaci, D., 2012. Direct Democracy and Minority Rights: Direct and Indirect Effects on Religious Minorities in Switzerland. Politics and Religion, 5 (01), 133-160.

Cronquist, L. and Berg-Schlosser, D., 2009. Multi-Values QCA (mvQCA). In B. Rihoux and C. Ragin, (eds) Configurational Comparative Methods: Qualitative Comparative Analysis (QCA) and Related Techniques. SAGE Publications, pp. 69-85.

Devers, K. J. et al., 2013. Using Qualitative Comparative Analysis (QCA) to Study PatientCentered Medical Homes. [online] Available from: https://www.urban.org/sites/ default/files/publication/24261/412969-Using-Qualitative-Comparative-AnalysisQCA-to-Study-Patient-Centered-Medical-Homes.PDF [Accessed 25 Jan 2018].

Dimitrijevic, I. \&Parausuc, A., 2017. Katalogbazapodatakazaistraživanja u oblastibezbednosti, Belgrade: Univerzitet u Beogradu - FakultetbezbednostiCentarzaprimenjenubezbednostFak ultetabezbednosti.

Dixon, M., Roscigno, V. and Hodson, R., 2004. Unions, Solidarity, and Striking. SOCIAL FORCES, 83(1).

Ekiert, G., Kubik, J. and Vachudova, M. A., 2007. Democracy in the Post-Communist World: An Unending Quest? East European Politics \& Societies, 21 (1), 7-30. [online] Available from: http://eep.sagepub.com/cgi/doi/10.1177/0888325406297170 [Accessed 25 Jan 2018].

Eric Rosenbach and Aki J. Peritz, 2009. Covert Action. BelferCenter for Science and International Affairs. [online] Available from: https://www.belfercenter.org/ publication/covert-action [Accessed 25 Jan 2018].

Fischer, M., 2014. Coalition Structures and Policy Change in a Consensus Democracy. Policy Studies Journal, 42 (3), 344-366. [online] Available from: http://doi.wiley. com/10.1111/psj.12064 [Accessed 25 Jan 2018].

Freedom House, COUCROS - Countries at the Crossroads. [online] Available from: https://freedomhouse.org/ [Accessed 25 Jan 2018]. 
Freedom House, WRPF - Freedom of the Press Freedom House. [online] Available from: https://freedomhouse.org/report-types/freedom-press [Accessed 25 Jan2018].

Gavranov, V. and Stojkovič, M., 1972. Teroijskoshvatanje sile: sila u međunarodnimodnosima.

Belgrade: SavremenaAdministracija.

Haesebrouck, T., 2017. NATO Burden Sharing in Libya. Journal of Conflict Resolution, 61 (10), 2235-2261. [online] Available from: http://journals.sagepub.com/doi/10.117 7/0022002715626248 [Accessed 25 Jan 2018].

Hart, B.L., 1954. Strategy the indirect approach., London: Faber and Faber.

Joireman, S.F., 2016. External Conditionalities and Institutional Change. East European Politics and Societies, 30 (2), 315-331. [online] Available from: http://journals. sagepub.com/doi/10.1177/0888325415593631 [Accessed 25 Jan 2018].

Kofman, M. and McDermott, R., 2015. No Return to Cold War in Russia's New Military Doctrine. Eurasia Review. [online] Available from: https://www.eurasiareview. com/03022015-no-return-cold-war-russias-new-military-doctrine-analysis/ [Accessed 25 Jan 2018].

Komar, O. and Živković, S., 2016. Montenegro: A democracy without alternations. East European Politics and Societies, 30 (4), 785-804. [online] Available from: http:// journals.sagepub.com/doi/10.1177/0888325416652229 [Accessed 25 Jan 2018].

Korybko, A., 2016. Hybrid Wars: Breaking the Balkans. Global Research - Centre for Research on Globalization. [online] Available from: https://www.globalresearch.ca/ hybrid-wars-breaking-the-balkans/5523932 [Accessed 31 Jan 2018].

Korybko, A., 2015. Hybrid Wars: The Indirect Adaptive Approach To Regime Change, The People's Friendship University of Russia. [online] Available from: http://newcoldwar.org/ wp-content/uploads/2015/08/Korybko-book-Hybrid-Wars.pdf [Accessed 25 Jan 2018].

Kulski, W., 1968. International policies in a revolutionary age. 2nd rev. (ed.), New York: Lippincott.

Liang, Q. and Xiangsui, W., 1999. Unrestricted Warfare. Beijing: PLA Literature and Arts Publishing House Arts.

Lind, W.S. et al., 1989. The Changing Face of War: Into the Fourth Generation. Marine Corps Gazette, October, pp. 22-26.

Lončar, J., 2016. Electoral Accountability and Substantive Representation of National Minorities: The Case of Serbia. East European Politics and Societies, 30(4), pp. 703724. [online] Available from: http://journals.sagepub.com/doi/10.1177/08883254166 50252 [Accessed 25 Jan 2018].

Mann, S., 1992. Chaos Theory and Strategic Thought., Ft. Belvoir: Defense Technical Information Center.

McCulloh, T. and Johnson, R., 2013. Hybrid warfare. JSOU Report 13-4. [online] Available from: http://www.dtic.mil/docs/citations/ADA591803. 
Messner, J., 1960. Mutiny - the Name of the Third World War (Мятежк имятретьейвсемирной) in: Е.Э. Месснер, Хочешьмира,победимятежевойну!, Mockва 2005, pp 101-175.

Messner, J., 1971. Mutinywar (Мятежевойна) In Е.Э. Месснер, Хочешьмира,победим ятежевойну!, Мосkва 2005, pp 392-476.

Mišović, S. and Kovač, M., 2006. Sistemiodbrane. Belgrade.

Mitrovic, M., 2017. Hybrid Security Threats and Contemporary Approach to National Security. Thematic Conference Proceedings of International Significance, International Conference 'Archibald Reiss Days', 1. [online] Available from: https://papers.ssrn.com/ sol3/papers.cfm?abstract_id=3070803 [Accessed 25 Jan 2018].

Nazemroaya, M. D., 2014. Iraq and Syria are Burning, "Constructive Chaos" and America's Broader Strategy to Conquer Eurasia. GlobalResearch.ca. [online] Available from: https://www.globalresearch.ca/iraq-and-syria-burning-a-collection-of-articlesabout-constructive-chaos-at-work/5388270 [Accessed 18 Feb 2018].

Nye, J. S., 2004. Soft power: The means to success in world politics. New York: Public Affairs.

Nye, J. S., 1990. Soft power. Foreign policy, Autumn.

Nye, J. S., 2011. The Future of Power. New York: Public Affairs.

Obradovic-Wochnik, J. and Wochnik, A., 2014. Invalid Ballots and the \&quot;Crisis of Representative Democracy: Re-inventing Protest at the 2012 Serbian Elections. East European Politics E Societies, 28 (4), 808-835.

Odak, S. and Benčić, A., 2016. Jasenovac-A Past That Does Not Pass: The Presence of Jasenovac in Croatian and Serbian Collective Memory of Conflict. East European Politics and Societies, 30 (4), 805-829.

Protsyk, O. and Sachariew, K., 2012. Recruitment and Representation of Ethnic Minorities under Proportional Representation: Evidence from Bulgaria. East European Politics $\mathcal{E}$ Societies, 26(2), 313-339. [online] Available from: http://eep.sagepub.com/cgi/doi/10. 1177/0888325410364672 [Accessed 6 Feb 2018].

Ragin, C., 2000. Fuzzy-set social science. University of Chicago Press.

Ragin, C., 2009. Qualitative Comparative Analyses Using Fuzzy Sets (fsQCA). In B. Rihoux and C. Ragin, (eds) Configurational Comparative Methods: Qualitative Comparative Analysis (QCA) and Related Techniques. SAGE Publications, pp. 87-121. [online] Available from: http://methods.sagepub.com/book/configurational-comparativemethods [Accessed 6 Feb 2018].

Ragin, C., 2009. Redesigning social inquiry: Fuzzy sets and beyond. University of Chicago Press.

Ragin, C., Mayer, S. and KA, D., 1984. Assessing discrimination: A Boolean approach. American Sociological Review. [online] Available from: https://www.jstor.org/ stable/2095572 [Accessed 25 Jan 2018]. 
Renz, B. and Smith, H., 2016. Russia and Hybrid warfare - going beyond the label. Aleksanteri Papers, 1.

Rihoux, B. and De Meur, G., 2009. Crisp-set Qualitative Comparative Analysis (csQCA). In B. Rihoux and C. Ragin (eds) Configurational Comparative Methods: Qualitative Comparative Analysis (QCA) and Related Techniques. SAGE Publications, pp. 33-68. [online] Available from: http://methods.sagepub.com/book/configurationalcomparative-methods [Accessed 6 Feb 2018].

Rihoux, B. and Ragin, C., 2009. Configurational Comparative Methods: Qualitative Comparative Analysis (QCA) and Related Techniques. London: Sage.

Savin, L., 2011. Network centric strategies in the Arab spring. Open Revolt! [online] Available from: https:/openrevolt.info/2011/12/29/network-centric-strategies/ [Accessed 28 Jan 2018].

Shashkov, S., 2011. The theory of 'manageable chaos' put into practice. Strategic Culture Foundation. [online] Available from: https://www.strategic-culture. org/news/2011/03/01/the-theory-of-manageable-chaos-put-into-practice.html [Accessed 6 Feb 2018].

Slipchenko, V., 1999. Voinabudushchego (War of the Future). Moscow.

Spirova, M. and Stefanova, B., 2012. The European Dimension of Minority Political Representation: Bulgaria and Romania Compared. East European Politics E Societies, 26 (1), 75-92. [online] Available from: http://eep.sagepub.com/cgi/doi/10.1177/0888 325410388831 [Accessed 25 Jan 2018].

Subotic, J., 2010. Explaining Difficult States: The Problems of Europeanization in Serbia. East European Politics E Societies, 24 (4), 595-616. [online] Available from: http:// eep.sagepub.com/cgi/doi/10.1177/0888325410368847 [Accessed 25 Jan 2018].

The Correlates of War Project, Correlates of War Project Website. [online] Available from: http://correlatesofwar.org/ [Accessed 25 Jan 2018].

Transparency International, Corruption Perceptions Index. CPI - Corruption Perceptions Index. [online] Available from: http://cpi.transparency.org [Accessed 25 Jan 2018].

Verweij, S. et al., 2013. What Makes Governance Networks Work? A Fuzzy Set Qualitative Comparative Analysis Of 14 Dutch Spatial Planning Projects. Public Administration, 91(4), 1035-1055.

Vis, B., 2011. Under which conditions does spending on active labor market policies increase? An fsQCA analysis of 53 governments between 1985 and 2003. European Political Science Review, 3(02), 229-252.

Watson, J., Chapter 3: Attack by Stratagem. In Sun Tzu's Art of War. [online] Available from: http://suntzusaid.com/book/3 [Accessed 25 Jan 2018].

Wright, R. A. and Boudet, H. S., 2012. To Act or Not to Act: Context, Capability, and Community Response to Environmental Risk. American Journal of Sociology, 118 (3), $728-777$. 